\title{
Advances in bone surgery: the Er:YAG laser in oral surgery and implant dentistry
}

This article was published in the following Dove Press journal:

Clinical, Cosmetic and Investigational Dentistry

29 June 2010

Number of times this article has been viewed

\section{Stefan Stübinger \\ Competence Center for Applied Biotechnology and Molecular Medicine, University of Zürich, Zürich, Switzerland}

Correspondence: Stefan Stübinger

Competence Center for Applied Biotechnology and Molecular Medicine, University of Zürich, Winterthurerstr. 260,

CH-8057 Zürich, Switzerland

$\mathrm{Tel}+4$ I 446358874

Fax +4| 446358917

Email stefan.stuebinger@cabmm.uzh.ch
Abstract: The erbium-doped yttrium aluminium garnet (Er:YAG) laser has emerged as a possible alternative to conventional methods of bone ablation because of its wavelength of $2.94 \mu \mathrm{m}$, which coincides with the absorption peak of water. Over the last decades in several experimental and clinical studies, the widespread initial assumption that light amplification for stimulated emission of radiation (laser) osteotomy inevitably provokes profound tissue damage and delayed wound healing has been refuted. In addition, the supposed disadvantage of prolonged osteotomy times could be overcome by modern short-pulsed Er:YAG laser systems. Currently, the limiting factors for a routine application of lasers for bone ablation are mainly technical drawbacks such as missing depth control and a difficult and safe guidance of the laser beam. This article gives a short overview of the development process and current possibilities of noncontact Er:YAG laser osteotomy in oral and implant surgery.

Keywords: carbonization, laser osteotomy, ablation, dental implants

\section{Introduction}

"Imagine an operating theatre in the year 2010. Instead of turning to the usual paraphernalia of stainless steel instruments spread across a green cloth, the surgeon uses a simple hand-held laser device". ${ }^{1}$ This vision for the future and forward-looking expectancy of light amplification for stimulated emission of radiation (laser) osteotomy was stated in 1995. After the first laser was introduced in 1960 by Theodore Maiman, the dawn of intraoral laser surgery was coming in 1964 with the development of the first continuous wave $(\mathrm{CW})$ carbon dioxide $\left(\mathrm{CO}_{2}\right)$ laser for soft tissue applications. ${ }^{2,3}$ Since then, the dream of laser-based "Star Wars" technology for oral surgery and implant dentistry has been a great incentive for research and industry to seek new bone cutting instruments. ${ }^{4-7}$ The following clinical experience as well as basic research led to fundamental improvements of laser-assisted bone cutting. The final breakthrough was achieved by the use of pulsed erbium-doped yttrium aluminium garnet (Er:YAG) lasers which showed efficient ablation rates with rare or noncarbonization phenomenon. Further technical improvements of erbium lasers in the field of operative dentistry during recent years led to a widespread acceptance of these devices for cutting and treatment of mineralized hard tissues. ${ }^{8-10}$

However, erbium lasers are currently still mainly applied for the preparation of dental hard tissues like enamel, dentin, and cementum. ${ }^{11-15}$ A sole and exclusive use of Er:YAG lasers for the treatment of bony tissue as a matter of routine is merely in fledgling stages and clinical trails demonstrating significant surgical benefits and long-term success are scarce. Cutting vital bone by erbium lasers would certainly offer 
many advantages, especially a noncontact, blood-reduced and vibration-reduced surgery techniques, free choice of cut geometry, a small operation field, and the prevention of massive bone flour and metal abrasion. ${ }^{16,17}$ In addition, the attenuation of the typical audible whining of dental high-speed handpieces as well as a reduced need for local anesthesia would make laser-assisted bone cutting an auspicious device for dentist-phobic patients. However, missing knowledge, inadequate training, and limited experience of surgeons often limit the use of this device to a small user domain. ${ }^{18}$

This article gives a short overview of the development process and current possibilities of noncontact Er:YAG laser osteotomy. This article aims to provide the clinician the most important information and background about Er:YAG laser-assisted bone cutting and to demonstrate the advantages and disadvantages of using a laser for different intraoral and extraoral indications.

\section{Historical background of laser-assisted bone cutting}

Since the introduction and first use of laser in the 1960s, a wide array of lasing media with unique radiant-energy wavelengths have been investigated and tested for coagulation, vaporization, and ablation of different hard and soft tissue structures. ${ }^{19-24}$ Initially, wavelengths developed for operative dentistry were primarily designed for soft tissue applications. Laser systems offered distinct advantages compared with conventional surgical procedures such as decreased bleeding tendency, less tissue traumatization with no need for sutures, reduced scar formation, and bacteriostasis. ${ }^{25-27}$ Besides beam delivery through mirrors via an articulated beam delivery system or a flexible fiber allowed minimal invasive and noncontact surgical procedures. However, due to the increasing demand for a reliable substitute for mechanical instruments such as chisels and band saws as well as oscillating saws and high-speed air turbines, there was an increasing urgency in oral and maxillofacial surgery for the development of more elaborate bone cutting techniques. ${ }^{28}$ As osteotomy of bony structures is often very challenging as thin and fragile bone segments of the maxilla and mandible are prone to fracture due to massive contact pressure and vibration by mechanical instruments, contact-free laser osteotomy presented itself to be a beneficial alternative. Furthermore, because of friction conventional processing of hard tissue can cause severe mechanical trauma, pain, and thermal damage to the adjacent remaining tissue. Moreover, the use of drills and saws often results in a broadening of cuts and a subsequent deposition of metal shavings and bacterial contamination.
Therefore, a major research focus was set on technical improvements of laser systems and on investigations of the biological effects of basic laser - tissue interaction. ${ }^{29,30}$ Potentially thermal side effects, such as melting, charring, or cracking had to be securely excluded. Experimental research and preliminary studies on the use of laser wavelengths for hard tissue ablation started in the early 1960s with the vaporization of enamel with a pulsed ruby laser. ${ }^{31}$ In the following decade, especially $\mathrm{CW}$ and long-pulsed medical $\mathrm{CO}_{2}$ lasers were tested for cutting mineralized tissue. $\mathrm{CO}_{2}$-laser wavelengths had already shown promising results for successful soft tissue treatment and thus helped establish the demand for laser osteotomy. ${ }^{32,33}$ However, the pioneering studies of Horch et $\mathrm{al}^{34,35}$ revealed serious biological complications with severe carbonization effects and a delayed bone healing compared with conventional mechanical osteotomies. These studies were the first serious attempt to replace the common and well-known established osteotomy methods with a laser system. Other reports using a selection of different $\mathrm{CO}_{2}$-laser parameters and experimental designs unveiled similar results..$^{36,37}$ In most instances, the excessive heat developments with critical temperatures over $47^{\circ} \mathrm{C}$ were the ultimate cause for severe damages of bony structures. ${ }^{38}$ Eriksson and Albrektsson ${ }^{39}$ demonstrated that temperature shifts between $44^{\circ} \mathrm{C}$ and $47^{\circ} \mathrm{C}$ in bone resulted in wound healing impairments and thermal damage. Charred tissue and a high amount of debris aggravated the whole surgical procedure.

During the late 1980s and 1990s, comprehensive advancements of short-pulsed infrared laser systems with appropriate wavelengths absorbed by biological hard tissue paved the way for successful ablation of dental hard substances and bone. Peavy et $\mathrm{al}^{40}$ stated that the best bone ablation results are reached with laser systems working in wavelengths of 2.9, 3.0, and 5.9-6.45 $\mu \mathrm{m}$. In this regard, the Er:YAG laser system appeared to be particularly suitable for cutting mineralized tissue. ${ }^{41,42}$ Studies by Hibst et $\mathrm{al}^{43-49}$ showed that middle-infrared laser systems allow an effective and clean thermo-mechanical ablation process. If laser wavelengths were strongly absorbed by the target tissue and pulse durations were below the thermal relaxation time of the tissue, ablation was possible with acceptable zones of thermal damage..$^{50}$ By additional adequate water cooling, tissue necrosis and charring could be dramatically reduced (Figure 1). ${ }^{51}$ Studies employing erbium laser wavelengths of $2.94 \mu \mathrm{m}$ (Er:YAG laser) and $2.78 \mu \mathrm{m}$ (Er,Cr:YSGG laser) found both systems to be efficient for dental hard tissue ablation. ${ }^{52,53}$ 


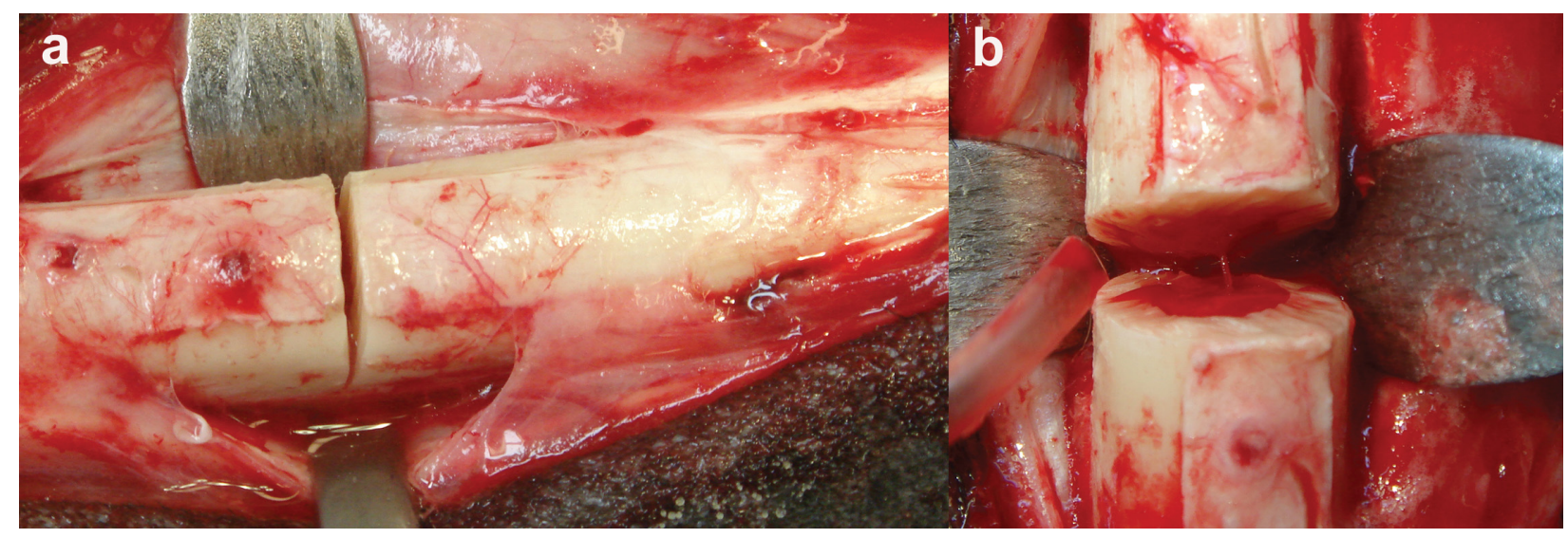

Figure I a) Precise and smooth osteotomy gap directly before final transaction of a sheep tibia. Er:YAG laser settings used for bone cutting were pulse energy of I,000 mJ, pulse duration of $300 \mu \mathrm{s}$, and a frequency of $12 \mathrm{~Hz}$ (energy density, I57 J/cm²). b) Clear bone surface of the osteotomy rim without any visible signs of carbonization or thermal damage. Further histological analysis revealed an undisturbed bone healing after 2 and 3 months that was even superior to conventional methods (submitted own results).

The main components of bone have a high absorption of the laser light at the wavelength $(2.94 \mu \mathrm{m})$ of the Er:YAG laser. ${ }^{54}$ The wavelength-dependent absorption coefficient for water is at its maximum peak at $2.94 \mu \mathrm{m}$. The Er:YAG laser theoretically has an absorption coefficient of water that is 10 and 15,000-20,000 times higher than the $\mathrm{CO}_{2}$ and the Nd:YAG lasers, respectively. ${ }^{55}$ Thus, it was not surprising that the erbium laser was finally the first dental laser cleared by the US Food and Drug Administration for use in cutting human teeth in vivo. ${ }^{56}$ Since then, however, critical comments on the introduction of such "a wondrous device" into operative dentistry have been stated. Mainly, the high costs of laser systems and the lack of profound and neutral appropriate investigations as well as clinical trails were excoriated by Walton..$^{57}$ "The rush is to sell, apparently with only minimal regard for the safety and welfare of patients". Keeping this in mind in the last 15 years, several studies on laser - tissue interactions as well as experimental and clinical trails were conducted to overcome the preconception that laser-assisted hard tissue ablation is mere science fiction.

\section{Laser-tissue interaction}

A laser device emits light through a process called stimulated emission. Laser light is characterized by a collimated (parallel) and coherent (temporally and spatially constant) electromagnetic radiation of a single wavelength. When laser irradiation reaches biological tissues (or any other material), not only physical laser features, but also specific tissue properties have to be carefully considered ${ }^{58,59}$ Laser wavelengths do not react with the same substances in the same way. Laser irradiation is mainly characterized by wavelength, exposure time, pulse frequency, pulse duration, spot size, power, and energy density. Tissue properties are characterized by optical, chemical, mechanical, and thermal qualities. ${ }^{60}$ Among optical qualities especially coefficients for absorption, reflection, refraction, and scattering are important for the amount of laser beam transmission, respectively absorption. ${ }^{61,62}$ For the clinician, 1 decisive factor for selecting a laser is to choose a wavelength that exhibits a maximal absorption by the components of the target tissue. ${ }^{63}$ Thermal properties such as heat conduction and heat capacity are responsible for overall heat development in the irradiated tissue. ${ }^{64}$ Temperature gradients produced within the tissue contribute to the overall effect of the laser. ${ }^{65}$ Depending on the individual laser and tissue variables, laser-tissue interactions can be generally divided into 5 categories: photochemical interaction, thermal interaction including thermo-mechanical ablation, photoablation, plasma-induced ablation, and photodisruption. ${ }^{66}$ For the treatment of biological hard tissue, thermo-mechanical ablation and photoablation occupy a central position. Essentially lasers for hard tissue ablation can be classified into 3 main groups: infrared lasers, excimer lasers, and "ultrashort"pulsed lasers.

For most medical laser systems, thermal interactions are of primary importance. Thermo-mechanical ablation is a thermal interaction since laser energy is absorbed in the tissue and transferred into heat energy. The thermal change in the target tissue leads to a chemical, physical, or mechanical alteration of the tissue structure or morphology ${ }^{67}$ Absorption is mainly contingent on incident laser wavelengths and on individual absorption coefficients of tissue inherent macromolecules. The speed of ablation is set so that almost no or only little heat is transferred to adjacent tissue. A further heat sink at the ablation zone and prevention of parching can be achieved 
by an additional water cooling spray. However, water spray is not only responsible for a heat sink, but also cleans the site of irradiation, increases ablation rate and efficiency, and facilitates the ablation process. ${ }^{68-70}$

Depending on the applied laser wavelength, tissue components like water or collagen are thoroughly heated very shortly after onset of laser irradiation. This "overheating" process happens extremely fast and provokes a high pressure build-up in the irradiated tissue volume due to the phase transition of water. The interstitial water is vaporized almost immediately and the following steam expansion exceeds the crystal strength of the irradiated hard tissue structures. This triggers a fragmentation and explosive ejection of hard tissue particles and debris in the form of localized microexplosions. ${ }^{71}$ Due to the Gaussian beam profile, the Er:YAG laser beam has high energy at its center, whereas at the outer region of the beam, the energy is low. Thus, tissue ablation is extremely efficient at the center, by thermal vaporization of the tissue. In contrast in adjacent tissue structures, the energy may be insufficient for tissue ablation, but sufficient to cause charring of bone tissue by the cumulative heat deposition after an amount of laser pulses in this area. For the thermo-mechanical ablation process, it is crucial that the pressure build-up time is shorter than the thermal relaxation time of the tissue. ${ }^{72}$ Only by this, the accumulated energy is effectively utilized for tissue removal. ${ }^{73-74}$ For the clinician, it is of particular importance to know that the rate and total amount of laser energy deposited into the target tissue can be dramatically affected by changing the spot size of the laser beam. ${ }^{75}$ A change of the beam diameter by a factor of 2 will change the incident power density by a factor of 4 . By manual guidance of the laser handpiece, the focus spot, respectively the beam diameter, can be defined and controlled by the surgeon. This will finally have an essential influence on the power density and intended laser-tissue interaction.

A further crucial point is the knowledge of the energy distribution in the beam. The distribution of photons across a beam is rarely uniform. Although beam diameter and energy or power densities provide necessary information for the clinician, such data are insufficient to obtain reproducible, comparable results for basic research. Meister et $\mathrm{al}^{76}$ demonstrated that laser ablation is highly dependent on the spatial beam profile. The energy distribution in the beam is unequal. Within the laser beam, local and radial energy centers generate circumscribed areas of high-energy density. This finally results in local energy density hotspots. ${ }^{77}$ As a consequence, determination of the surface area which is actually irradiated is hardly possible. Yet for an exact calculation of the applied energy flux density and ablation volume this is indispensable. Normally as a rule, however, the laser user has no knowledge of the beam profile and there is no way of easy checking, influencing or, if necessary, even modifying the beam profile of a commercial laser system.

Hard tissue interaction of erbium lasers is characteristically accompanied by a pooping sound (photoacoustic effect), which is a quick shock wave induced by fast dissipation of laser energy. ${ }^{78}$ Especially short-pulsed laser systems with a high-energy density show up a photoacoustic effect. The final result is a thermal decomposition which has to be clearly distinguished from photoablation which is defined as a direct breaking of molecular bonds by high-energy photons. Photons are directly absorbed without a thermal influence. Photoablation is a very clean and precise ablation of mineralized hard tissue which is mainly achieved by short ultraviolet (UV) wavelengths of excimer lasers. ${ }^{79,80}$ Due to the high absorption in collagen and low absorption in water, heat distribution into adjacent tissue structures is minimal after the use of excimer lasers. ${ }^{81,82}$ Additional water cooling does not disturb the ablation process. Therefore, photoablation is more or less an athermal ablation process which would offer ideal conditions for bone cutting. ${ }^{83,84}$ However, extremely low ablation rates per pulse and difficult handling of excimer lasers reduce their scale of clinical usability. There are some reports in literature that showed distinct tissue trauma, represented by osteocyte destruction and impaired bone healing, because of photoacoustic damage. ${ }^{85}$ In addition, a certain risk of mutagenic effects of the UV radiation could not be excluded and thus limited the application of excimer lasers in bone surgery. ${ }^{86,87}$ Hence, cutting bone by means of the excimer laser is very time consuming and not recommended for surgical procedures under local anesthesia as the compliance and patience of the patient is taxed.

A similar limitation of low ablation rates is encountered with ultrashort-pulsed lasers. Even though experimental and clinical data revealed promising results in terms of thermal tissue interaction, these laser systems are merely suitable for high precision osteotomy of very extremely small and thin bone structures. ${ }^{88}$ Therefore, thermo-mechanical tissue ablation with infrared lasers especially erbium lasers, is clinically still seen as the most reliable and forward-looking technique.

Finally, it has to be stated that the definite process sequence of thermo-mechanical dental hard tissue ablation by lasers has not yet been adequately explained. Although, on the one hand, tissue dehydration by temperatures far beyond physiological values $\left(<200^{\circ} \mathrm{C}\right)$ are discussed, on 
the other a cavitation effect or acceleration of water droplets (hydrokinetics) are hypothesized. ${ }^{89-92}$ Ongoing research will unveil further information and insights into basic principles of laser-tissue interaction mechanisms. In this regard, modern computer technology and software developments also offer a great potential of evaluating new treatment protocols and theoretical analysis of laser-tissue interactions. The possibility of modeling laser-tissue interaction by a computer program was already tested by London et $\mathrm{al}^{93}$ in the late 1990s. The authors described that the computer program could be used to study the effects of dynamic optical properties on dosimetry in photothermal therapy. Interactions could be divided into the processes of laser propagation, thermal effects, material effects, and hydrodynamics. For researchers as well as clinicians, such computer models allow new and unprecedented prospects for virtual simulations of different clinical environments and analysis of basic principles of laser effects on biological tissues.

\section{Experimental Er:YAG laser osteotomy \\ The foundations for Er:YAG laser osteotomy: the 1990s}

In the early 1990s, the influence of erbium lasers on bony tissue was mainly compared with Holmium-YAG or Neodymium-YAG lasers systems. Charlton et al ${ }^{94}$ could demonstrate that the erbium laser caused a zone of secondary damage to surrounding tissue of about $5 \mu \mathrm{m}$, whereas this zone was greatly increased to $80 \mu \mathrm{m}$ with significant charring in the case of holmium. Similar results were presented by Buchelt et $\mathrm{al}^{95}$ In a histological and biomechanical (torque testing) study in rat tibiae, the authors compared bone healing after the use of an Er:YAG and Ho:YAG lasers with a power saw. Although Ho:YAG laser-treated osteotomies exhibited formation of dense fibrous tissue, carbonization, and no callus formation within 12 weeks, Er:YAG and saw osteotomies provoked a certain reunion within 8 weeks. Radiographs after Ho:YAG laser osteotomies showed a clear pseudoarthrosis. Holmium-YAG laser seemed to be inappropriate for bone cutting and thus further studies in the 1990s mainly compared Er:YAG laser osteotomy with conventional osteotomy techniques and $\mathrm{CO}_{2}$ lasers.

A direct comparison of a metal bur to a free-running Er:YAG laser (fixed Q mode, pulse duration $250 \mu \mathrm{m}$, spot size $0.75 \mathrm{~mm}$, and 5 pulses $/ \mathrm{s}$ ) disclosed the migration of fibroblasts from the periosteum after laser ablation in rat tail bones after 9 and 10 days. ${ }^{96}$ Although there was a secondary damage to the adjacent tissue, bone healing was not completely constrained. Similar results of retarded bone formation by delayed resorption of devitalized tissue after Er:YAG laser ablation with various energy densities $\left(13,25\right.$, and $\left.38 \mathrm{~J} / \mathrm{cm}^{2}\right)$ were found in rat calvarial critical size defects. ${ }^{97}$ Laser treatment left an amorphous, mineralrich carbon layer at the surfaces of the osteotomy site. After 105 days, the defects had not been bridged by new bone. In fact a wedge-shaped, rounded mass of new bone was attached to the periphery of the defect by ectocranial and endocranial apposition with no evident union between the new bone and the ablated surface. Er:YAG laser ablation demonstrated a loss of organic matrix and biological activity which adversely affect guided tissue regeneration. However, as stated by the authors, the free exposure of bone minerals in the modified surface layer after laser treatment could play a vital role for stimulating successive bone repair in a further course. Findings by Lewandrowski et $\mathrm{al}^{98}$ pointed in this direction. In contrast to former studies, the authors did not find any difference in the amount of newly formed woven bone after the application of either an Er:YAG laser or rotary instruments in rat mandibles. Fluence per pulse was typically $60 \mathrm{~J} / \mathrm{cm}^{2}$. The extent of a thermally affected zone (25-100 $\mu \mathrm{m})$ near the osteotomy gap was comparable at laser and drill sites. Except for 1 animal, in all other cases an endochondral callus formation and an extensive periosteal bone formation were apparent after 4 weeks. The authors clearly pointed out that their findings differed from previous studies that reported delayed healing of osteotomy sites performed by mid-infrared Er:YAG lasers. A crucial issue for such results may be seen in the animal model in the surgical site. In contrast to rat tail bones and calvarial defects, rat mandibles offer a superior blood supply and functional stimulation for bone repair.

Nelson et $\mathrm{al}^{99}$ used rabbit tibiae in their study evaluating different osteotomy techniques. In contrast to a mechanical saw, Er:YAG laser ablation revealed a delayed bone healing in this study due to a microscopic zone of tissue damage. Yet laser cuts produced sharp edges and no gross charring or burning of adjacent bone. These in vivo experiments were based on previous results from the same group disclosing that the zone of thermal injury after Er:YAG laser ablation with increasing laser energy was much more pronounced in methacrylate than in rabbit long bones. ${ }^{100}$ Thus in vital tissue, the thermal effects of laser treatment were much more complex and heat distribution had a much stronger influence on adjacent structures. A further influence of laser parameters on tissue damage was demonstrated by Walsh et $\mathrm{al}^{101}$ In their study analyzing Er:YAG laser ablation of skin, cornea, aorta, and bone, Q-switched pulses caused less thermal damage, 
typically $5-10 \mu \mathrm{m}$ of damage in all tissue. Walsh et al ${ }^{101}$ could also show that pulse fluences greater than $20 \mathrm{~J} / \mathrm{cm}^{2}$ caused plasma formation by which ablation efficiency was decreased. However, also too low pulse fluences were able to prevent efficient ablation of bone, because of desiccation. ${ }^{102}$ Further analysis of different laser parameters on the thermal outcome was performed by Romano. ${ }^{103} \mathrm{He}$ could demonstrate that cutting depth of laser osteotomy was linearly related to the number of laser pulses and that repetition rates above $20 \mathrm{~Hz}$ did not provoke significant thermal stress to the bone. Another important study by Shori et al ${ }^{104}$ disclosed that an increasing absorption of Er:YAG laser irradiation by water molecules subsequently led to changes in their chemical bonding. The absorption peak for water shifted to shorter wavelengths and thus effectiveness of laser ablation dwindled and in return thermal exposure increased. Therefore, a steady control of heat development by water cooling and maintenance of low energy settings is crucial for avoiding accidental thermal tissue trauma. Generally, the amount of tissue water and additional cooling water play a vital role for effective laser ablation. Previous analysis of surface morphology of Holmium-YAG laser ablation craters had already revealed distinct differences for fresh and dehydrated bone specimen. ${ }^{105}$ Dry cortical bone demonstrated the presence of fibers which reflected the selective removal of inorganic surface bone constituents with preservation of subsurface residual collagen fibers. In contrast, crater walls in wet tissues appeared much rougher probably due to a more violent ablation process by explosive water vaporization. Analysis of fresh as well as frozen cadaver septal cartilage and maxillary sinus bone after Er:YAG and $\mathrm{CO}_{2}$-laser ablation disclosed similar histological differences of bony specimen. ${ }^{106}$ The authors own unpublished results with a short-pulsed Er:YAG laser supported these findings. There were striking differences of ablation volume and cutting efficiency of the laser beam in fresh, frozen, or thawed horse bones.

\section{Bone healing after Er:YAG laser osteotomy}

Almost a decade after substantial research investigating the scope of Er:YAG laser osteotomy and laser - tissue interactions, studies by Sasaki et $\mathrm{al}^{107}$ further analyzed ultrastructural alterations of bone samples after irradiation with pulsed Er:YAG and $\mathrm{CO}_{2}$ lasers as well as conventional techniques. In parietal bones of Wistar rats, Er:YAG laser ablation (100 mJ/pulse, $10 \mathrm{~Hz}$, and $1 \mathrm{~W}$ ) caused a superficial changed layer (13.2-30 $\mu \mathrm{m}$ thickness), which consisted of 2 distinct sublayers: a superficial layer, where numerous microcracks gave a porous appearance and a dark and less affected deep layer, which had less microcracks. Energy dispersive X-ray spectroscopy demonstrated that the changed superficial layer with $\mathrm{Ca}$ and $\mathrm{P}$ components produced by $\mathrm{CO}_{2}$-laser irradiation was almost 5 times thicker than that produced by the Er:YAG laser. One reason might have been the high absorption coefficient of hydroxyapatite at $10.6 \mu \mathrm{m}$, where the $\mathrm{CO}_{2}$ laser emitted. It is about 4-9 times higher than that of water. Consequently, most of the laser energy was absorbed by the mineral phase and caused an overheating of the hard tissue. However, because of recrystallization processes of the original apatites and also reduction of surrounding organic matrix Er:YAG laser ablation showed unimpressive results. In a following study of the same group, scanning electron microscopy and Fourier transformed infrared spectroscopy (FTIR) analysis of bone revealed more promising results for the Er:YAG laser. ${ }^{108}$ Although surfaces after Er:YAG treatment at $100 \mathrm{~mJ} /$ pulse and a pulse rate of $10 \mathrm{~Hz}(1 \mathrm{~W})$ were characterized by well-defined edges and no superficial smear layer, $\mathrm{CW} \mathrm{CO}_{2}$-laser ablation provoked a distinct melting and carbonization with minimal tissue removal. Chemical composition of the bone surface after Er:YAG laser ablation was almost unchanged (FTIR). By contrast, $\mathrm{CO}_{2}$-laser ablation in this experiment induced the production of toxic substances. A further comparison of Er:YAG laser ablation (contact and noncontact mode) with similar laser parameters (115 mJ/pulse, $10 \mathrm{~Hz}$ ) and electrosurgery showed no severe thermal damage of bony tissue 12 months postsurgery. ${ }^{109}$ A superficially affected layer with a microstructured surface did not impede new bone formation. In contrast, electrosurgery led to a large area of thermal necrosis which was not replaced with new bone. Although these results led to the assumption that Er:YAG laser osteotomy might be more advantageous than $\mathrm{CO}_{2}$-laser osteotomy, some studies disclosed different results. Comparison of a free-running Er:YAG and 9.6- $\mu \mathrm{m}$ transverse-excited $\mathrm{CO}_{2}$ lasers for ablation of bovine skull tissue revealed a zone of peripheral thermal damage of about 25-40 $\mu \mathrm{m}$ for the Er:YAG laser (pulse duration, $300 \mu \mathrm{s}$; pulse duration, $0.5 \mu \mathrm{s}) .{ }^{110}$ No discernible thermal damage was seen in samples ablated with $\mathrm{CO}_{2}$ pulse durations of 5 and $8 \mu \mathrm{s}$. However, considerable charring was noticeable at longer pulse durations $(20-100 \mu \mathrm{s})$. In all cases no additional water spray was used. Similar results with short-pulsed $\mathrm{CO}_{2}$ lasers were published by other groups with improved beam parameters. ${ }^{111,112}$ Eyrich $^{113}$ could demonstrate the use of a 9.6- $\mu \mathrm{m} \mathrm{CO}_{2}$ laser as a bone cutting tool could be considered as a safe method with minimal thermal damage. In series of ex vivo trials with porcine bone mean temperature rises with 
a super-pulsed $\mathrm{CO}_{2}$ laser using different laser settings were merely $1.88^{\circ} \mathrm{C}$. In contrast, Er:YAG laser osteotomy resulted in a mean rise of $3.3^{\circ} \mathrm{C}$. Ultimately, a short-pulsed $\mathrm{CO}_{2}$-laser osteotome in a multipass mode using a computer-controlled galvanic beam scanner and an assisting water spray showed convincing results. ${ }^{114,115}$

An altered superficial tissue layer $(\sim 24 \mu \mathrm{m})$ was also detected by de Mello et al ${ }^{116}$ after pulsed Er:YAG laser ablation in a rat tibia model. The modified zone was composed of 2 different sublayers: a superficial nonstructural layer $(\sim 15 \mu \mathrm{m})$ and a deeper charred $1(\sim 9 \mu \mathrm{m})$. However, after 7 days osteotomy sites were completely filled with new immature trabecular bone. After 21 days, mature cortical and bone marrow was evident. In fact after 7 and 14 days, laser sites presented a more advanced bone remodeling than the control group (bur drilling). The authors explained the superior healing tendency by a mechanically propitious surface structure that allowed a strong adhesion of the coagulum.

In pursuit of highlighting the advantages of Er:YAG laser osteotomy, Pourzarandian et $\mathrm{al}^{117}$ further analyzed the early healing process of bone tissue irradiated by Er:YAG and $\mathrm{CO}_{2}$ lasers and a mechanical bur. Er:YAG laser irradiation was performed with an energy output of $100 \mathrm{~mJ} /$ pulse at a pulse repetition rate of $10 \mathrm{~Hz}(1 \mathrm{~W})$. Ten minutes after Er:YAG laser ablation, an aggregation of red blood cells in a varying density was noted spreading over the treated bone surface. At 6 and 24 hours, and 3, 7, and 14 days, initial events of bone healing and general healing appeared to progress at a faster pace in the Er:YAG group than in the $\mathrm{CO}_{2}$ and conventional group. Osteotomy sites after Er:YAG laser ablation exhibited more prominent inflammatory cell infiltration, revascularization, and proliferation of fibroblasts and osteoblasts, indicating active osteoid tissue formation. The authors concluded that the irregular surface structure after Er:YAG laser ablation with no smear or char layers provided a favorable surface for cell attachment and thus accelerated bone healing and formation. To determine the most efficient energy per pulse for intraoral osteotomies, Papadaki et al ${ }^{118}$ employed an Er:YAG laser with a pulse rate of $10 \mathrm{~Hz}$, a pulse duration of $300 \mu \mathrm{s}$, and a beam spot size of $1 \mathrm{~mm}$ diameter. They performed vertical ramus osteotomies in 2 fresh pig mandibles, 1 pig cadaver head, and 1 human mandible with energy densities of $63.6,127,191$, and $255 \mathrm{~J} / \mathrm{cm}^{2}$, respectively, using pulse settings of 500, 1,000, 1,500, and 2,000 $\mathrm{mJ} /$ pulse, respectively. Times needed for the osteotomies ranged from 28 minutes with $500 \mathrm{~mJ} /$ pulse to 5.33 minutes with 2,000 $\mathrm{mJ} /$ pulse in the pig mandibles. Macroscopically, the authors did not observe any charring or plasma as long as the laser beam was moved quickly over the bone. The most challenging part for the surgeon was to maintain the same distance, focus and course of the beam along the bone, during the time period required to make the cut. Ultimately even though no adverse effects on the bone surface could be detected, the manual handling with a certain risk of tissue trauma limited the clinical usability of the system. A comparable problem and limitation of the clinical applicability of a pulsed Er:YAG laser for a lateral access osteotomy to the maxillary sinus of animal and human cadaver heads could be demonstrated by the own group. ${ }^{119}$ In contrast to the study to Sohn et al ${ }^{120}$ which demonstrated promising results with an Er,Cr:YSGG for a laser-assisted sinus graft procedures, authors' own results revealed devastating effects concerning the preservation of the sinus membrane. Even though in all sites Er:YAG laser osteotomy was possible without any visible carbonization or thermal damage, missing depths control caused significant destructions of the membrane $(100 \%)$. Therefore, it was concluded that laser-assisted access osteotomy for maxillary sinus elevation did not seem to be currently clinically practicable and reliable. Technical drawbacks still limited an unrestricted use of lasers in daily routine. However, the dogma of severe thermal damage and long osteotomies times could be finally overcome.

In this respect also, a recent histological evaluation of the effects of Er:YAG laser osteotomy by Akyol et al ${ }^{121}$ demonstrated that bone can be ablated effectively and precisely with this wavelength. The authors created a bone defect in the femur of rats with the Er:YAG laser (energy density, 1.5 W) and compared bone healing with a surgical bone drill. After 10 and 20 days, no significant difference between groups could be found. In a following study, the same group compared bone healing in diabetic rats after ostectomies obtained by Er:YAG laser and bur drilling. ${ }^{122}$ Applying same laser parameters, the authors did not find any carbonizing effects or collateral damage to surrounding tissue. No significant differences among the groups for remodeling in spongiosa and bone marrow could be detected. In summary, the Er:YAG laser could be confidently used for ablation of normal and diabetic bone without any histological detectable damage. The only disadvantage was a slower cutting performance of the laser in comparison to the mechanical instruments.

\section{Laser implant drilling: possibilities and limitations}

An atraumatic preparation of the implant bed essentially determines the inception and progress of subsequent bone healing and thus a sound interfacial bonding between 
implant and bone. ${ }^{123}$ A gentle surgical technique also leads to an enhanced initiation of bone remodeling with a stronger stability of implants especially in the early phase of healing. ${ }^{124}$ Therefore, different Er:YAG laser systems were also tested for implant bed preparation. In the late 1990s, el Montaser et al ${ }^{125}$ could demonstrate that osseointegration of titanium screws can be achieved using an Er:YAG laser to prepare implant channels. At 3 weeks, titanium screws with a diameter of $1 \mathrm{~mm}$ were surrounded by vital woven bone in rat calvarial model. Implants were placed in drill holes with a diameter of $0.7 \mathrm{~mm}$ with slight bone condensation. Except for a thin zone of necrotic bone on the osteotomy surface, no further laser-related damages could be observed. Finally at 3 months, there were no differences between laser and drill groups concerning osseointegration. In a further study, Salina et al ${ }^{126}$ prepared 1-mm wide and 2-mm long implant sites for the insertion of mini-implants into the tibia of rabbits with a pulsed Er:YAG laser. The laser was used with a sapphire tip on a contra-angle handpiece with a $1.0-\mathrm{mm}$ diameter in a virtual point source mode $(200 \mathrm{~mJ}$ and $30 \mathrm{~Hz}$ ). Comparison to a traditional drill protocol revealed no irreversible damages, even though a carbonized amorphous tissue layer could be detected in the early stages of the healing process. Therefore, implant healing after 7-15 days was faster in the drilling group than in the laser group. After 30 days postoperatively, no implant was lost and bone regeneration as well as osseointegration was comparable at all implant sites. The carbonized tissue layer was progressively resorbed in a way similar to conventional bone grafts. Neither osseointegration nor periimplant bone remodeling were impeded. Osseointegration after Er:YAG laser disclosed to be efficient without inducing irreversible damages. An undisturbed bone healing after Er:YAG laser-assisted implant bed preparation was also demonstrated by Schwarz et al. ${ }^{127}$ In a dog model, bone ablation was performed with a pulsed Er:YAG laser in focused mode $(15 \mathrm{~Hz}, 300 \mathrm{~mJ}$, and spot size $0.2 \mathrm{~mm}$ ) with a calculated energy density of $35 \mathrm{~J} / \mathrm{cm}^{2}$. Even though after 2 weeks significant differences of the bone-toimplant-contact-line between drill $(48.5 \% \pm 11.08 \%)$ and laser $(34.5 \% \pm 7.76 \%)$ groups could be identified, after 12 weeks no significant differences could be found between laser (64.1\% $\pm 8.97 \%)$ and drill (68.94\% $\pm 11.23 \%)$ groups. In general, histological observation of the adjacent alveolar bone revealed no identifiable signs of any thermal side effects such as carbonization, melting, or cracking in both groups at 2 and 12 weeks. However, manual guided laser osteotomy frequently resulted in wide periimplant gaps particularly in the apical area of the implant supporting bone. Anyhow between 2 and 12 weeks these gaps were spanned with newly formed bone. The authors concluded that laser irradiation did not compromise bone regeneration and subsequent osseointegration of common dental titanium implants.

Similar or even superior results for Er:YAG laser-assisted implant drilling could be demonstrated by Kesler et al ${ }^{128}$ in a rat tibia model. Implant sites were either prepared with a conventional drill or a pulsed Er:YAG laser. The laser was used with a spot size of $2 \mathrm{~mm}$, pulse duration of $400 \mathrm{~ms}$, frequency of $10 \mathrm{~Hz}$, and an energy density of $16-32 \mathrm{~J} / \mathrm{cm}^{2}$. The bone volume removed per pulse was $1.4 \mathrm{~mm}^{3}$. The authors report that after 3 weeks respectively 3 months, osseointegration of unloaded implants of the laser group (59.48\%; 73.54\%) disclosed significant higher bone-to-implant-contact-values than the corresponding drill group (12.85\%; 32.65\%). Newly formed woven bone was observed in close contact with the titanium surface. However, laser implant drilling displayed distinct technical problems and disadvantages. To guarantee an almost cylindrical laser cavity a special gauge was necessary, because manual laser guidance did not allow comparable sizes and diameters of implant channels. Furthermore, continuous pooling of blood drastically slowed down ablation efficiency. The authors own unpublished results using a various square-pulsed (VSP) Er:YAG laser revealed similar results. Without the use of a special template is was hardly feasible to create standardized implant channels for commercial dental implants. Laser implant beds were not perfectly congruent to the cylindrical implant geometry especially in the most apical part (irregular floor space and deviated side walls) due to slight and unavoidable deviations of laser beam angulations. Yet time need for laser implant drilling was not prolonged in comparison to a conventional drill and osseointegration was not disturbed.

It can, therefore, be concluded that implant site preparation using an Er:YAG laser does not impede periimplant wound healing and osseointegration. Nevertheless for clinical use in daily routine, known technical drawbacks of the manual guidance still limit the application of laser systems for a safe and beneficial implant site preparation. Even though bone healing and remodeling revealed successful and forward-looking results, the potential risk of accidental or uncontrolled tissue damage do currently not justify a routine application in humans.

\section{Clinical application of Er:YAG laser osteotomy in oral surgery}

In the last 2 decades, different lasers systems were tested for their clinical practicability and implementation into the 
operation theatre to overcome the limitations of conventional methods. ${ }^{129-136}$ Advanced osteotomies were possible without profound physiologic complications and the contact-free application with an almost unlimited cut geometry offered distinct advantages for the surgeons. ${ }^{137,138}$ In a randomized controlled clinical trial, Abu-Serriah et al ${ }^{139}$ showed that after Er:YAG laser-assisted removal of third molars no persistent complications were clinically encountered. The Er:YAG laser beam was transmitted through a flexible hollow wave-guide arm (pulse energy, $700 \mathrm{~mJ}$; pulse duration, $250 \mu \mathrm{s}$; and pulse frequency $10 \mathrm{~Hz}$ ). Subjective as well as objective postoperative assessments revealed that the Er:YAG laser could be considered as an alternative to surgical drills in anxious patients, but the routine use of it in its current specification was time consuming. In the following, Lee could also demonstrate viable and reasonable results with an Er:Cr,YSGG laser. ${ }^{140}$ Harvesting of intraoral bone grafts from the ramus as well as removal of third molars from the mandible were possible without major clinical or technical complications. Bone cutting was similar to the conventional technique without any biological adverse effects.

However, even though successful laser osteotomy with less or almost no carbonization effects could be proven in these preliminary studies, long osteotomies times and a sophisticated handling were apparently reasons for not using the technique. ${ }^{141,142}$ The authors own results using an Er:YAG laser with a fiber-optic delivery system for the removal of wisdom teeth showed no thermal damage to adjacent bone and soft tissue structures, but time need for osteotomies was prolonged (Figure 2). ${ }^{143}$ Similar findings could be observed when the system was used for intraoral bone grafting procedures (Figure 3). ${ }^{144}$ For the osteotomies, the laser settings included a pulse energy of $500 \mathrm{~mJ}$, a pulse duration of $250 \mu \mathrm{s}$, and a pulse frequency of $12 \mathrm{~Hz}$. During osteotomy, the laser fiber tip was kept 1-2 mm away from the bone surface (Figure 4).

Only in the wake of a new VSP Er:YAG laser with pulse profiles that are nearly square shaped and thereby allowing an almost constant power within the pulses, the disadvantage of prolonged osteotomy times could be overcome. ${ }^{145}$ In dental hard substances, the ablation rates of the VSP Er:YAG laser were even higher than those obtained with mechanical handpieces. ${ }^{146,147}$ A definite advantage of the VSP power supply technology is that the pulse modality is not uncontrollably shifting during a pulse among hot, warm, and cold ablation regimes. Consequently thermal stress to the bone can be limited. Based on these prerequisites, less traumatic osteotomies of bone structures could be performed in a

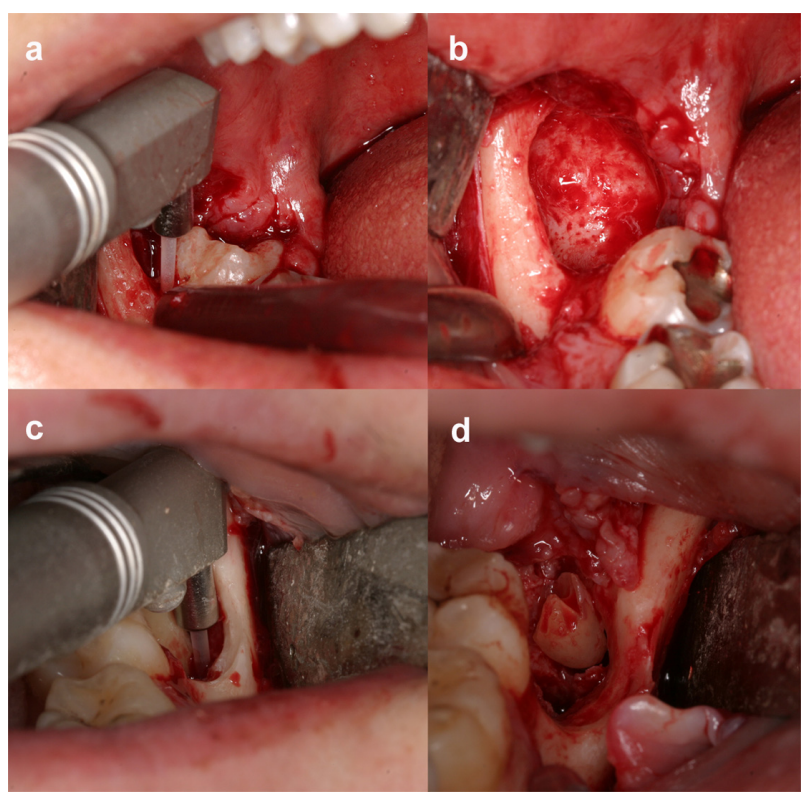

Figure 2 a) Osteotomy of a right impacted molar. The Er:YAG laser is guided carefully around the tooth. Er:YAG laser settings used for bone cutting were pulse energy of $500 \mathrm{~mJ}$, a pulse duration of $250 \mu \mathrm{s}$, and a frequency of $12 \mathrm{~Hz}$. In this case, a distance of $\mathrm{I}-2 \mathrm{~m}$ was maintained between the laser $\mathrm{I}, 000 \mu \mathrm{m}$ fiber (energy density, $64 \mathrm{~J} / \mathrm{cm}^{2}$ ). b) View of the surgery site following osteotomy with the fiber-optic delivery system. No carbonization and no thermal damage are visible. c) Removal of an impacted third molar in the left mandible with the articulated arm delivery laser system. The fiber could be easily guided around the teeth using the lateral contact with surrounding bone without additional or uncontrolled bone loss. The only limitation of cut depth was the thickness and diameter of the fiber. d) Finally also impacted root remnants could be safely removed by laser ablation.

reasonable amount of time and without any thermal damages or wound healing impairments. Noncontact bone cutting with the VSP Er:YAG laser revealed not only convincing clinical results, but also allowed new and forward-looking treatment regimes. A histological analysis of fresh human

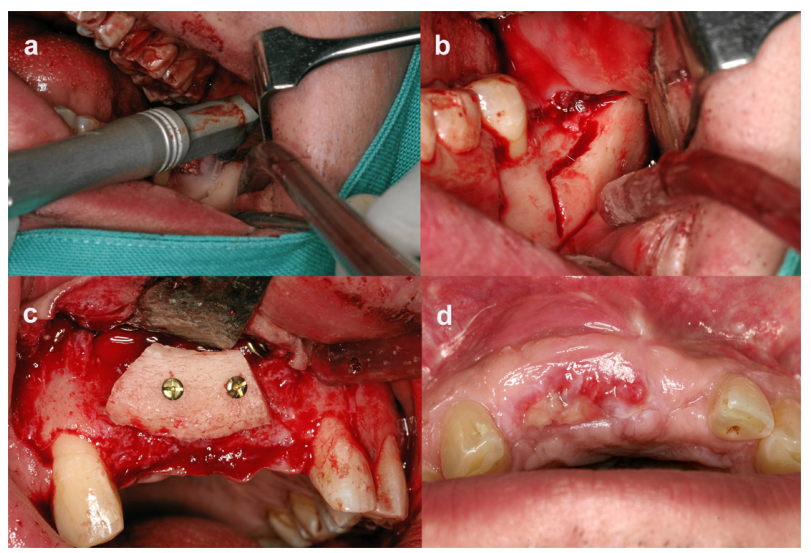

Figure 3 a) Harvesting of a block graft from the left ramus region. Intraoperative view of the surgery site following Er:YAG laser osteotomy with the fiber-optic delivery system. b) The bone graft was lased out fluently without making orientation holes before or outlining the shape. c) Fixation of the bone graft with 2 titanium screws at the recipient site in the frontal maxilla. d) Postoperative wound healing ( 10 days) was without complications. Only a slight soft tissue dehiscence occurred due to a not perfect fitting removable prosthesis. 


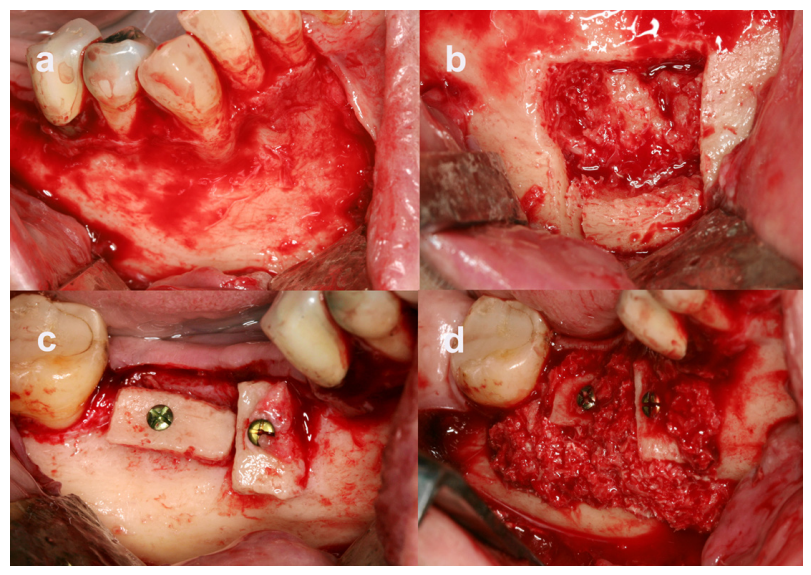

Figure 4 a) View of the right symphyseal donor site after flap elevation. b) Donor site after block removal. The lingual cortex is not damaged and there are no signs of carbonization. As bone volume by I graft was too less for an alveolar ridge augmentation, a second block was lased out apically to the first. c) Fixation of the 2 blocks each with I titanium screw at the recipient site in the right mandible. d) In addition, allogenic bone substitutes were put around the blocks.

bone specimen after VSP Er:YAG laser ablation disclosed that the laser left behind a 5-10 $\mu \mathrm{m}$ superficial demarcation zone as a characteristic fingerprint, in which the homogenous lamellar bone matrix structure was changed to a diffuse fibrous-like structure. ${ }^{148}$ Osteocyte lacunae directly adjacent to the laser fingerprint contained osteocytes with normal structural characteristics. In a further clinical study, the own group used the same laser system for harvesting intraoral bone grafts with a spot size of $0.9 \mathrm{~mm}$ at a distance of about $10 \mathrm{~mm}$ from the bone surface. ${ }^{149}$ The laser settings used for bone cutting were pulse energy of $1,000 \mathrm{~mJ}$, pulse duration of $300 \mu \mathrm{s}$, and a frequency of $12 \mathrm{~Hz}$ (energy density, $157 \mathrm{~J} / \mathrm{cm}^{2}$ ). By contact-free laser guidance over the surface, various cut courses with straight or curved parts could be easily combined without the need of changing any surgical tips. The laser beam could be directed in all directions and the fluency of the cutting was not disturbed or interrupted by any technical prerequisites. Cortical as well as cancellous bone could be smoothly cut until a depth of $15 \mathrm{~mm}$. Deeper cuts were also possible, but then limited ablation rate and sight reduced cutting efficiency. Osteotomy gaps were precise and thin and revealed no bony particles or debris in form of a superficial smear layer on the rim. Cut width and accuracy were depending on the focus spot size of the laser $(0.9 \mathrm{~mm})$ and the constant manual control of the surgeon. This dependency on the surgical and operating experiences of the surgeon was a major challenge, ie, any deviation or change of the primarily determined angulation of the laser beam led to a tremendous loss of bone volume and depth control during osteotomy was based on continuous visual

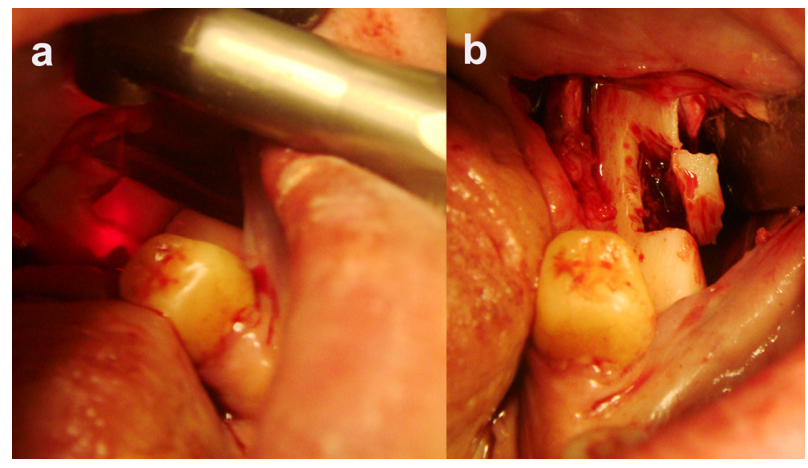

Figure 5 a) Harvesting of a block graft from the left ramus region with a VSP Er: YAG laser (pulse energy, I,000 mj; pulse duration, $300 \mu$ s; frequency, $12 \mathrm{~Hz}$; and energy density, $157 \mathrm{~J} / \mathrm{cm}^{2}$ ). The visible red pilot beam of the laser handpiece indicates the spot area of later laser ablation. b) Osteotomy site after Er:YAG laser ablation. The geometry of the bone graft and the typical craggy cutting kerf are visible. Less experience of the surgeon and distinct deviations of the original angulation of the laser beam led to significant bone loss of the bone graft on the surface and the depth.

surveillance by the surgeon (Figure 5). Although no direct tactile depth control was possible during laser surgery, there was no severe iatrogenic damage to any vital structures. The well-directed water cooling spray together with the missing bony particles following osteotomy allowed a clear sight and examination. Noncontact laser osteotomy was especially of advantage in clinical situations where thin bony structures had to be preserved or limited application pressure was necessary.

Another new and interesting approach for the use of the Er:YAG laser is the ablation of necrotic bone and adjacent tissue structures in course of the therapy on bisphosphonaterelated osteonecrosis (BON) of jaw bones. The first successful and stable results after Er:YAG laser ablation of BON lesions were recently described in literature. ${ }^{150}$ Surgical sites treated with a VSP Er:YAG laser showed up a clinical improvement of $100 \%$ at a mean follow-up of 13 months. Bone resection or evaporation of the necrotic areas was obtained with a VSP Er:YAG laser, using either $250 \mathrm{~mJ}, 20 \mathrm{~Hz}$, and a fluence of $50 \mathrm{~J} / \mathrm{cm}^{2}$ or $300 \mathrm{~mJ}, 30 \mathrm{~Hz}$, and a fluence of $60 \mathrm{~J} / \mathrm{cm}^{2}$. Besides the removal of necrotic and surrounding bone by the erbium laser, the sites underwent a supplemental low-level laser therapy) with a NY:YAG laser.

In a further study by Angiero et al ${ }^{151}$ Er:YAG laser treatment of $\mathrm{BON}$ lesions led to significant improvements in clinical parameters. Treatment consisted of initially removing the necrotic bone tissue with a VSP Er:YAG laser at a power setting of 200-250 mJ and $10 \mathrm{~Hz}$. An $800-\mu \mathrm{m}$ fiber with water spray was applied. In addition, a subsequent decontamination and biostimulation were performed at a power setting of $50 \mathrm{~mJ}$ and $15 \mathrm{~Hz}$ using the same fiber for $60 \mathrm{~s}$. Energy fluences ranged from 27 to $54 \mathrm{~J} / \mathrm{cm}^{2}$. The authors 
own clinical results with a VSP Er:YAG supported these findings, even though laser parameters were different and no additional biostimulation was performed. ${ }^{152}$ By a reduced initial inflammatory response and superior soft tissue healing, laser treatment of bone showed itself as a promising alternative to conventional mechanical instruments. These findings demonstrate the advantageous effect of laser irradiation on bone and support the hypothesis that laser will not only be an innovative and highly beneficial tool to cut vital bone, but also reveals high potential in the treatment of bone malformations and lesions.

\section{Technical improvements for safe laser osteotomies}

Generally, the application of laser systems is profitable when they offer new and beneficial therapeutic possibilities in contrast to commonly accepted conventional methods. ${ }^{153-155}$ However, due to the crucial missing of depth control laser osteotomy is still assessed to be inferior to other bone cutting techniques like high-speed drills or piezoelectric devices. Even though the contact-free mode is highly beneficial for precise and arbitrary cut geometries, the lack of a tactile feedback is a striking restriction and elimination of the manual skills and experience of the surgeon. Therefore, the control of an accurate bone removal depth is difficult. Only visual inspection and intermittent application of gauges enable the surgeon to assess and guarantee a certain amount of tissue volume ablation and depth.

To solve this problem, different approaches have been proposed and recommended in literature. Except for innovative computer-assisted $\mathrm{CO}_{2}$-laser system, most of the technical design and developments rely on erbium lasers. ${ }^{156}$ A recent approach concentrated on the creation of defined geometries by navigated laser ablation based on volumetric 3-dimensional (3-D) data. ${ }^{157-159}$ On the basis of computed tomography data, cylindrical cavities in bovine bone were planned with the help of a navigation system. ${ }^{160}$ The position of the laser handpiece was optically tracked and the distance to the bone surface was calculated. The authors applied a free focused Er:YAG laser without a special scanner system. On the basis of a special mathematical model, theoretical cavity depth for each single laser pulse was calculated and visualized by the navigation system. Ongoing material removal was determined in a volume model. The system allowed visualizing the laser ablation process with an error of less than $1 \mathrm{~mm}$. However, 1 continuous problem in this experimental set up was that only a planar positioning system was used. In a clinical environment, the laser will be operated manually which will definitely complicate the practicability of the system. The authors already reported that they had "difficulties adjusting the laser freehand based on the visualized navigation data". A further limitation of the model is the simple assumption "that the properties of the treated tissue are constant and homogeneous". Even though laser ablation of mineralized tissue is characterized by removal of an almost fixed amount of material per laser pulse, a clinically determinable control of cutting depth by calculating the ablated bone volume by means of a volume model with single-volume elements of bone (voxels) is hardly feasible. Due to the inhomogeneity of cortical and cancellous bone as well as the additional volume of supplemental cooling water, blood and bony debris shielding the osteotomy site laser - tissue interactions are strongly affected. Bone is a heterogeneous substance that contains a variety of different components that vary between different individuals and may even vary within the bone structure and morphology of a single person. Depending on the actual energy density striking on the bone surface, laser cutting efficiency is differing and consequently also the quantity of tissue ablation and cutting depth is distinctly fluctuating per single laser pulse. Therefore, overall ablation depth varies even if constant laser parameters are applied. Nevertheless, this innovative approach has to be finally evaluated in a clinical situation.

A different approach was described by Rupprecht et $\mathrm{al}^{161,162}$ using a special feedback system to control laser drilling of cortical bone with an Er:YAG laser (energy density, $450 \mathrm{~mJ} / \mathrm{mm}^{2}$ ) under water spray cooling. Laser ablation of organic tissue is characterized and accompanied by different acoustical, optical, and thermal signals. The signals can be detected by different sensor systems to control the laser process and to cut tissue without damaging adjacent structures. ${ }^{163}$ Assisted by the sensor-based feedback system, a tissue-specific cutting with the Er:YAG laser was demonstrated in minipig jaws, with ablation rates between 20 and $60 \mathrm{~mm} /$ pulse. This could be achieved because the detected signals which changed in a characteristic way after the cortical bone layer had been passed. A histomorphometric analysis revealed a mean ablation rate of cortical bone of almost 99\%. Microcomputer tomography evaluation confirmed highly precise, specific, and efficient bone ablation that was limited to cortical bone and had no effect on the underlying cancellous bone. Using the selective laser osteotomy technique, vitally important soft tissue structures in the vicinity of the laser cut, such as the inferior alveolar nerve, could be preserved from potential harm by laser irradiation. This approach of tissue-specific cutting by different sensor systems 
seems to have a high potential for future developments of highly precise and safe laser osteotomy. Further studies in clinical environment will have to prove its actual usability in the operation theatre.

In spite of such innovative and forward-looking approaches and developments to considerably improve the handling and reliability of laser osteotomy, inconsistent description of laser settings as well as subjective knowledge and experience of scientific groups with their laser system limit the overall amount of findings. Therefore to objectively compare results using different laser settings, the group around Beer ${ }^{164}$ introduced a standardized test assembly. In the test assembly, specimen is adjusted on a special object table in $\mathrm{x}$ and $\mathrm{y}$ coordinates. The $\mathrm{z}$-axis is standardized by a spacer and an optical distance control for an uneven surface can be applied. The movable table is controlled by computerassisted stepper motors which allow consistent movements of the specimen, meaning that the motion over the $\mathrm{x}$-axis and y-axis is smooth and without jolts. Preliminary results revealed an improvement in accuracy (50-fold) in comparison to a manual guidance of the same laser beam. The authors stated that "due to its technical details, as well as parameters that can be defined and selected freely, it is suitable for the realization of the necessary comparative studies with lasers". Future studies will have to evaluate this new and interesting device for different laser and operational management.

Eventually, new laser technologies like powerful and diode pumped fiber lasers will extend the application spectrum of laser systems and stimulate the market for further developments. ${ }^{165}$ Together with modern facilities of telemedicine, virtual 3-D and 4-D computer planning as well as real-time navigation systems lasers will become a more universal and safe tool for visionary and innovative treatment options in bone surgery.

\section{Conclusions}

The Er:YAG laser offers significant advantages over other conventional osteotomy techniques like a noncontact intervention, no mechanical vibration, free and elaborate cut geometries and aseptic effects. ${ }^{166}$ Over the last decades in several experimental and clinical studies, the widespread initial assumption that laser osteotomy inevitably provokes profound tissue damage and delayed wound healing could be refuted. In addition, the well-known disadvantage of prolonged osteotomy times could be overcome by modern Er:YAG laser systems. Currently, the limiting factors for a routine application of lasers for bone ablation are mainly technical drawbacks like missing depth control in conjunction with a difficult and safe guidance of the laser beam. Nevertheless with adequate training and experience, the surgeon is able to use this device for certain and selective surgical procedures in oral surgery and implant dentistry. In this regard, however, not only ethical aspects, but also and even more important the real advantage and scope of using a laser for the intended clinical indication have to be carefully considered. With further developments like special miniature laser systems, depth control feedback systems, and robotic guidance, new clinical indications and applications will undoubtedly arise. This will make the Er:YAG laser to a state of the art and innovative bone cutting technique with a high potential for future applications and trends in oral surgery and implant dentistry.

\section{Acknowledgments}

Parts of this work were supported by scientific grants from the National Center of Competence in Research CO-ME of the Swiss National Science Foundation, Berne, Switzerland, and the camlog foundation, Basle, Switzerland. The authors gratefully acknowledge Fotona, Ljubljana, Slovenia, for kindly supplying the laser equipment.

\section{Disclosure}

The author reports no conflicts of interest in this work.

\section{References}

1. Thompson C. Laser tackles bone. Lancet. 1995;345(8956):1001.

2. Maiman TH. Stimulated optic radiation in ruby. Nature. 1960;187: 493-494.

3. Wlodawsky RN, Strauss RA. Intraoral laser surgery. Oral Maxillofac Surg Clin North Am. 2004;16(2):149-163.

4. Zakariasen KL, Dederich DN, Tulip J. Lasers in dentistry. "Star wars." Dreaming or a future reality? J Can Dent Assoc. 1988;54(1):27-30.

5. Cernavin I, Pugatschew A, de Boer N, Tyas MJ. Laser applications in dentistry: a review of the literature. Aust Dent J. 1994;39(1):28-32.

6. Margolis FS. The erbium laser: the "Star Wars" of dentistry. Alpha Omegan. 2006;99(3):128-131.

7. Weesner BW Jr. Lasers in medicine and dentistry: where are we now? J Tenn Dent Assoc. 1998;78(1):20-25.

8. Colvard MD, Pick RM. Future directions of lasers in dental medicine. Curr Opin Periodontol. 1993:144-150.

9. Willenborg GC. Dental laser applications: emerging to maturity. Lasers Surg Med. 1989;(4):309-313.

10. Gertzbein SD, deDemeter D, Cruickshank B, Kapasouri A. The effect of laser osteotomy on bone healing. Lasers Surg Med. 1981;1(4): 361-373.

11. Parker S. Surgical lasers and hard dental tissue. Br Dent J. 2007;202(8): 445-454.

12. van As G. Erbium lasers in dentistry. Dent Clin North Am. 2004;48(4): 1017-1059.

13. Iaria G. Clinical, morphological, and ultrastructural aspects with the use of Er:YAG and Er,Cr:YSGG lasers in restorative dentistry. Gen Dent. 2008;56(7):636-639.

14. Gimbel CB. Hard tissue laser procedures. Dent Clin North Am. 2000; 44(4):931-953. 
15. Bader C, Krejci I. Indications and limitations of Er:YAG laser applications in dentistry. Am J Dent. 2006;19(3):178-186.

16. Pearson GJ, Schuckert KH. The role of lasers in dentistry: present and future. Dent Update. 2003;30(2):70-74.

17. Anic I, Miletic I, Krmek SJ, Borcic J, Pezelj-Ribaric S. Vibrations produced during erbium:yttrium-aluminum-garnet laser irradiation. Lasers Med Sci. 2009;24(5):697-701.

18. Martin E. Lasers in dental implantology. Dent Clin North Am. 2004; 48(4):999-1015.

19. Ishikawa I, Aoki A, Takasaki AA, Mizutani K, Sasaki KM, Izumi Y. Application of lasers in periodontics: true innovation or myth? Periodontol 2000. 2009;50:90-126.

20. Mohammadi Z. Laser applications in endodontics: an update review. Int Dent J. 2009;59(1):35-46.

21. Wigdor HA, Walsh JT Jr, Featherstone JD, Visuri SR, Fried D, Waldvogel JL. Lasers in dentistry. Lasers Surg Med. 1995;16(2): 103-133.

22. Adams TC, Pang PK. Lasers in aesthetic dentistry. Dent Clin North Am. 2004;48(4):833-860.

23. Salmos J, Gerbi ME, Braz R, Andrade ES, Vasconcelos BC, Bessa-Nogueira RV. Methodological quality of systematic reviews analyzing the use of laser therapy in restorative dentistry. Lasers Med Sci. 2010;25(1):127-136.

24. Sulieman M. An overview of the use of lasers in general dental practice: 2 . Laser wavelengths, soft and hard tissue clinical applications. Dent Update. 2005;32(5):286-288.

25. Ishii J, Fujita K, Komori T. Laser surgery as a treatment for oral leukoplakia. Oral Oncol. 2003;39(8):759-769.

26. Alster TS, Handrick C. Laser treatment of hypertrophic scars, keloids, and striae. Semin Cutan Med Surg. 2000;19(4):287-292.

27. Wang $X$, Zhang C, Matsumoto K. In vivo study of the healing processes that occur in the jaws of rabbits following perforation by an Er,Cr:YSGG laser. Lasers Med Sci. 2005;20(1):21-27.

28. Sulewski JG. Historical survey of laser dentistry. Dent Clin North Am. 2000;44(4):717-752.

29. Frentzen M, Koort HJ. Lasers in dentistry: new possibilities with advancing laser technology? Int Dent J. 1990;40(6):323-332.

30. Zakariasen KL, Dederich DN. Dental lasers and science. J Can Dent Assoc. 1991;57(7):570-573.

31. Stern RH, Sognnaes RF. Laser beam effect on dental hard tissue. J Dent Res. 1964;43:873.

32. Pick RM, Colvard MD. Current status of lasers in soft tissue dental surgery. J Periodontol. 1993;64(7):589-602.

33. Tuncer I, Ozçakir-Tomruk C, Sencift K, Cöloğlu S. Comparison of conventional surgery and $\mathrm{CO}_{2}$ laser on intraoral soft tissue pathologies and evaluation of the collateral thermal damage. Photomed Laser Surg. 2010;28(1):75-79.

34. Horch HH, McCord RC, Keiditsch E. Histological and long term results following laser osteotomy. In: Kaplan I, editor. Laser Surgery II. Jerusalem: Academic Press; 1978:318.

35. Horch HH. Current status of laser osteotomy. Orthopade. 1984;13(2): 125-132.

36. Clayman L, Fuller T, Beckman H. Healing of continuous-wave and rapid superpulsed, carbon dioxide, laser-induced bone defects. J Oral Surg. 1978;36(12):932-937.

37. Gopin BW, Cobb CM, Rapley JW, Killoy WJ. Histologic evaluation of soft tissue attachment to $\mathrm{CO}_{2}$ laser-treated root surfaces: an in vivo study. Int J Periodontics Restorative Dent. 1997;17(4):316-325.

38. Eriksson RA, Adell R. Temperatures during drilling for the placement of implants using the osseointegration technique. J Oral Maxillofac Surg. 1986;44(1):4-7.

39. Eriksson RA, Albrektsson T. Temperature threshold levels for heat-induced bone tissue injury. A vital microscopic study in rabbit. J Prosthet Dent. 1983;50(1):101-107.

40. Peavy GM, Reinisch L, Payne JT, Venugopalan V. Comparison of cortical bone ablations by using infrared laser wavelengths 2.9 to 9.2 microm. Lasers Surg Med. 1999;25(5):421-434.
41. Bader C, Krejci I. Indications and limitations of Er:YAG laser applications in dentistry. Am J Dent. 2006;19(3):178-186.

42. Bornstein ES, Lomke MA. The safety and effectiveness of dental Er:YAG lasers. A literature review with specific reference to bone. Dent Today. 2003;22(10):129-133.

43. Hibst R, Keller U. Heat effect of pulsed Er:YAG laser radiation. Laser surgery: advanced characterization of therapetics and systems. Proc SPIE. 1990;1200:379-386.

44. Hibst R, Keller U. Experimental studies of the application of the Er:YAG laser on dental hard substances: I. Measurement of the ablation rate. Lasers Surg Med. 1989;9(4):338-344.

45. Keller U, Hibst R, Mohr W. Tierexperimentelle Untersuchungen zur Laserosteotomie mit dem Er:YAG Laser. Dtsch Z Mund Kiefer Gesichtschir. 1991;15(3):197-199.

46. Keller U, Hibst R. Experimental studies of the application of the Er:YAG laser on dental hard substances: II. Light microscopic and SEM investigations. Lasers Surg Med. 1989;9(4):345-351.

47. Hibst R, Keller U. Effects of water spray and repetition rate on the temperature elevation during Er:YAG laser ablation of dentine. Proc SPIE. 1995;2623:139-144.

48. Hibst R. Mechanical effects of erbium:YAG laser bone ablation. Lasers Surg Med. 1992;12(2):125-130.

49. Keller U, Hibst R. Ablative effect of an Er:YAG laser on enamel and dentin. Dtsch Zahnarztl Z. 1989;44(8):600-602.

50. Spencer P, Payne JM, Cobb CM, et al. Effective laser ablation of bone based on the absorption characteristics of water and proteins. J Periodontol. 1999;70(1):68-74.

51. Fried D, Ragadio J, Akrivou M, Featherstone JD, Murray MW, Dickenson KM. Dental hard tissue modification and removal using sealed transverse excited atmospheric-pressure lasers operating at lambda=9.6 and 10.6 microm. J Biomed Opt. 2001;6(2):231-238.

52. Iaria G. Clinical, morphological, and ultrastructural aspects with the use of Er:YAG and Er,Cr:YSGG lasers in restorative dentistry. Gen Dent. 2008;56(7):636-639.

53. Convissar RA. The biologic rationale for the use of lasers in dentistry. Dent Clin North Am. 2004;48(4):771-794.

54. Kang HW, Oh J, Welch AJ. Investigations on laser hard tissue ablation under various environments. Phys Med Biol. 2008;53(12): 3381-3390.

55. Schwarz F, Aoki A, Sculean A, Becker J. The impact of laser application on periodontal and peri-implant wound healing. Periodontol 2000. 2009;51:79-108.

56. Cozean C, Arcoria CJ, Pelagalli J, Powell GL. Dentistry for the 21st century? Erbium:YAG laser for teeth. J Am Dent Assoc. 1997;128(8): 1080-1087.

57. Walton RE. Technology versus biology - where are we headed? Oral Surg Oral Med Oral Pathol Oral Radiol Endod. 1997;84(5):457.

58. Dederich DN, Bushick RD. Lasers in dentistry: separating science from hype. J Am Dent Assoc. 2004;135(2):204-212.

59. Reinisch L. Laser physics and tissue interactions. Otolaryngol Clin North Am. 1996;29(6):893-914

60. Peavy GM. Lasers and laser-tissue interaction. Vet Clin North Am Small Anim Pract. 2002;32(3):517-534.

61. Fisher JC. Photons, physiatrics, and physicians: a practical guide to understanding laser light interaction with living tissue, part I. J Clin Laser Med Surg. 1992;10(6):419-426.

62. Herd RM, Dover JS, Arndt KA. Basic laser principles. Dermatol Clin. 1997;15(3):355-372.

63. van Gemert MC, Welch AJ. Clinical use of laser-tissue interactions. EEE Eng Med Biol Mag. 1989;8(4):10-13.

64. van Gemert MJ, Lucassen GW, Welch AJ. Time constants in thermal laser medicine: II. Distributions of time constants and thermal relaxation of tissue. Phys Med Biol. 1996;41(8):1381-1399.

65. Jacques SL. Laser-tissue interactions. Photochemical, photothermal, and photomechanical. Surg Clin North Am . 1992;72(3):531-558.

66. Niemz M. Laser-Tissue Interactions-Fundamentals and Applications. 3rd editor. Berlin Tokyo: Springer; 2004. 
67. Thomsen S. Pathologic analysis of photothermal and photomechanical effects of laser-tissue interactions. Photochem Photobiol. 1991;53(6): $825-835$.

68. Fried D, Ashouri N, Breunig T, Shori R. Mechanism of water augmentation during IR laser ablation of dental enamel. Lasers Surg Med. 2002;31(3):186-193.

69. Mir M, Meister J, Franzen R, Sabounchi SS, Lampert F, Gutknecht N. Influence of water-layer thickness on Er:YAG laser ablation of enamel of bovine anterior teeth. Lasers Med Sci. 2008;23(4):451-457.

70. Colucci V, do Amaral FL, Pécora JD, Palma-Dibb RG, Corona SA. Water flow on erbium:yttrium-aluminum-garnet laser irradiation: effects on dental tissues. Lasers Med Sci. 2009;24(5):811-818.

71. Nuss RC, Fabian RL, Sarkar R, Puliafito CA. Infrared laser bone ablation. Lasers Surg Med. 1988;8(4):381-391.

72. Choi B, Welch AJ. Analysis of thermal relaxation during laser irradiation of tissue. Lasers Surg Med. 2001;29(4):351-359.

73. Coluzzi DJ. Fundamentals of dental lasers: science and instruments. Dent Clin North Am. 2004;48(4):751-770.

74. Clarkson DM. A review of technology and safety aspects of erbium lasers in dentistry. Dent Update. 2001;28(6):298-302.

75. Welch AJ, Torres JH, Cheong WF. Laser physics and laser-tissue interaction. Tex Heart Inst J. 1989;16(3):141-149.

76. Meister J, Apel C, Franzen R, Gutknecht N. Influence of the spatial beam profile on hard tissue ablation. Part I: multimode emitting Er:YAG lasers. Lasers Med Sci. 2003;18(2):112-118.

77. Meister J, Franzen R, Apel C, Gutknecht N. Influence of the spatial beam profile on hard tissue ablation, part II: pulse energy and energy density distribution in simple beams. Lasers Med Sci. 2004;19(2):112-118.

78. Li ZZ, Reinisch L, van de Merwe WP. Bone ablation with Er:YAG and $\mathrm{CO}_{2}$ laser: study of thermal and acoustic effects. Lasers Surg Med. 1992;12(1):79-85.

79. Murray AK, Dickinson MR. Tissue ablation-rate measurements with a long-pulsed, fibre-deliverable $308 \mathrm{~nm}$ excimer laser. Lasers Med Sci. 2004;19(3):127-138.

80. Frentzen M, Koort HJ, Thiensiri I. Excimer lasers in dentistry: future possibilities with advanced technology. Quintessence Int. 1992;23(2):117-133.

81. Nakamura Y, Hossain M, Watanabe H, Tokonabe H, Matsumoto N, Matsumoto K. Morphological changes of rat mandibular bone with ArF excimer laser in vivo. J Clin Laser Med Surg. 1999;17(4):145-149.

82. Yow L, Nelson JS, Berns MW. Ablation of bone and polymethylmethacrylate by an $\mathrm{XeCl}$ (308 nm) excimer laser. Lasers Surg Med. 1989;9(2):141-147.

83. Dressel M, Jahn R, Neu W, Jungbluth KH. Studies in fiber guided excimer laser surgery for cutting and drilling bone and meniscus. Lasers Surg Med. 1991;11(6):569-579.

84. Haffner C, Folwaczny M, Hickel R, Horch HH. Ablation of temporomandibular joint structures of a pig with a fibre-guided 308-nm excimer laser light - an in vitro investigation. J Craniomaxillofac Surg. 2004;32(6):360-364.

85. Lustmann J, Ulmansky M, Fuxbrunner A, Lewis A. Photoacoustic injury and bone healing following $193 \mathrm{~nm}$ excimer laser ablation. Lasers Surg Med. 1992;12(4):390-396.

86. Kochevar IE. Cytotoxicity and mutagenicity of excimer laser radiation. Lasers Surg Med. 1989;9(5):440-445.

87. Wong BJ, Dickinson MR, Berns MW, Neev J. Identification of photoacoustic transients during pulsed laser ablation of the human temporal bone: an experimental model. J Clin Laser Med Surg. 1996; 14(6):385-392.

88. Armstrong WB, Neev JA, Da Silva LB, Rubenchik AM, Stuart BC. Ultrashort pulse laser ossicular ablation and stapedotomy in cadaveric bone. Lasers Surg Med. 2002;30(3):216-220.

89. Walsh JT, Hill DA. Erbium laser ablation of bone: effect of water content. Proc SPIE. 1991;1427:27-33.

90. Burkes EJ Jr, Hoke J, Gomes E, Wolbarsht M. Wet versus dry enamel ablation by Er:YAG laser. J Prosthet Dent. 1992;67(6):847-851.
91. Holcomb DW, Young RA. Thermal decomposition of human teeth enamel. Calcif Tissue Int. 1980;31(3):189-201.

92. Wigdor HA, Walsh JT, Visuri SR. Effect of water on dental materials ablation of the Er:YAG laser. Proc SPIE. 1994;2128:267-272.

93. London RA, Glinsky ME, Zimmerman GB, Bailey DS, Eder DC, Jacques SL. Laser-tissue interaction modeling with LATIS. Appl Opt. 1997;36(34):9068-9074.

94. Charlton A, Dickinson MR, King TA, Freemont AJ. Erbium-YAG and holmium-YAG laser ablation of bone. Lasers Med Sci. 1990;5: 365-373.

95. Buchelt M, Kutschera HP, Katterschafka T, et al. Erb:YAG and Hol:YAG laser osteotomy: the effect of laser ablation on bone healing. Lasers Surg Med. 1994;15(4):373-381.

96. Devlin H, Dickinson M, Freemont AJ, King T, Lloyd R. Healing of bone defects prepared using the Erbium-YAG laser. Lasers Med Sci. 1994;9:239-242.

97. el Montaser MA, Devlin H, Sloan P, Dickinson MR. Pattern of healing of calvarial bone in the rat following application of the erbium - YAG laser. Lasers Surg Med. 1997;21(3):255-261.

98. Lewandrowski KU, Lorente C, Schomacker KT, Flotte TJ, Wilkes JW, Deutsch TF. Use of the Er:YAG laser for improved plating in maxillofacial surgery: comparison of bone healing in laser and drill osteotomies. Lasers Surg Med. 1996;19(1):40-45.

99. Nelson JS, Orenstein A, Liaw LH, Berns MW. Mid-infrared erbium:YAG laser ablation of bone: the effect of laser osteotomy on bone healing. Lasers Surg Med. 1989;9(4):362-374.

100. Nelson JS, Yow L, Liaw LH, et al. Ablation of bone and methacrylate by a prototype mid-infrared erbium:YAG laser. Lasers Surg Med. 1988; 8(5):494-500.

101. Walsh JT Jr, Flotte TJ, Deutsch TF. Er:YAG laser ablation of tissue: effect of pulse duration and tissue type on thermal damage. Lasers Surg Med. 1989;9(4):314-326.

102. Walsh JT Jr, Deutsch TF. Er:YAG laser ablation of tissue: measurement of ablation rates. Lasers Surg Med. 1989;9(4):327-337.

103. Romano V. Bone micorsurgery with IR lasers: a comparative study of the thermal action at different wavelengths. Proc SPIE. 1994;2077:87-97.

104. Shori RK, Waltson AA, Stafsudd OM, Fried D, Walsh JT. Quantification and modeling of the dynamic changes in the absorption coefficient of water at $2.94 \mu \mathrm{m}$. IEEE J Sel Top Quantum Electron. 2001;7:959-970.

105. Wong BJF, Liaw LL, Neev J, Berns MW. Scanning electron microscopy of otic capsule and calvarial bone ablated by a holmium-YAG laser. Lasers Med Sci. 1994;9:249-260.

106. Gonzalez C, van de Merwe WP, Smith M, Reinisch L. Comparison of the erbium-yttrium aluminum garnet and carbon dioxide lasers for in vitro bone and cartilage ablation. Laryngoscope. 1990;100(1):14-17.

107. Sasaki KM, Aoki A, Ichinose S, Ishikawa I. Ultrastructural analysis of bone tissue irradiated by Er:YAG Laser. Lasers Surg Med. 2002;31(5): 322-332.

108. Sasaki KM, Aoki A, Ichinose S, Yoshino T, Yamada S, Ishikawa I. Scanning electron microscopy and Fourier transformed infrared spectroscopy analysis of bone removal using Er:YAG and $\mathrm{CO}_{2}$ lasers. $J$ Periodontol. 2002;73(6):643-652.

109. Yoshino T, Aoki A, Oda S, et al. Long-term histologic analysis of bone tissue alteration and healing following Er:YAG laser irradiation compared to electrosurgery. J Periodontol. 2009;80(1):82-92.

110. Fried NM, Fried D. Comparison of Er:YAG and 9.6-microm TE $\mathrm{CO}(2)$ lasers for ablation of skull tissue. Lasers Surg Med. 2001;28(4): 335-343.

111. Ivanenko MM, Fahimi-Weber S, Mitra T, Wierich W, Hering P. Bone tissue ablation with sub-microS pulses of a Q-switch $\mathrm{CO}(2)$ laser: histological examination of thermal side effects. Lasers Med Sci. 2002;17(4):258-264.

112. Stanislawski M, Meister J, Mitra T, Ivanenko MM, Zanger K, Hering P. Hard tissue ablation with a free-running Er:YAG and a Q-switched $\mathrm{CO}_{2}$ laser: a comparative study. Appl Phys B. 2001;72:115-120. 
113. Eyrich G. Laser-osteotomy induced changes in bone. Med Laser Appl. 2005;20:25-36.

114. Kuttenberger JJ, Waibel A, Stübinger S, et al. Bone healing of the sheep tibia shaft after carbon dioxide laser osteotomy: histological results. Lasers Med Sci. 2010;25(2):239-249.

115. Ivanenko M, Sader R, Afilal S, Werner M, et al. In vivo animal trials with a scanning $\mathrm{CO}_{2}$ laser osteotome. Lasers Surg Med. 2005;37(2): 144-148.

116. de Mello ED, Pagnoncelli RM, Munin E, et al. Comparative histological analysis of bone healing of standardized bone defects performed with the Er:YAG laser and steel burs. Lasers Med Sci. 2008;23(3):253-260.

117. Pourzarandian A, Watanabe H, Aoki A, et al. Histological and TEM examination of early stages of bone healing after Er:YAG laser irradiation. Photomed Laser Surg. 2004;22(4):342-350.

118. Papadaki M, Doukas A, Farinelli WA, Kaban L, Troulis M. Vertical ramus osteotomy with Er:YAG laser: a feasibility study. Int J Oral Maxillofac Surg. 2007;36(12):1193-1197.

119. Stübinger S, Nuss K, Sebesteny T, Saldamli B, Sader R, von Rechenberg B. Erbium-doped yttrium aluminium garnet laser-assisted access osteotomy for maxillary sinus elevation: a human and animal cadaver study. Photomed Laser Surg. 2010;28(1):39-44.

120. Sohn DS, Lee JS, An KM, Romanos GE. Erbium, chromium:yttriumscandium-gallium-garnet laser-assisted sinus graft procedure. Lasers Med Sci. 2009;24(4):673-677.

121. Akyol UK, Güngörmüs M, Gündogdu C, Erdem H. Histologic evaluation of the effects of Er:YAG laser on bone ablation. J Contemp Dent Pract. 2009;10(5):65-72.

122. Akyol U, Güngörmüş M. Er:YAG laser ablation of bone in experimental diabetics. Photomed Laser Surg. 2009. doi:10.1089/pho.2008.2479.

123. Sharawy M, Misch CE, Weller N, Tehemar S. Heat generation during implant drilling: the significance of motor speed. J Oral Maxillofac Surg. 2002;60(10):1160-1169.

124. Wu X, Deng F, Wang Z, Zhao Z, Wang J. Biomechanical and histomorphometric analyses of the osseointegration of microscrews with different surgical techniques in beagle dogs. Oral Surg Oral Med Oral Pathol Oral Radiol Endod. 2008;106(5):644-650.

125. el Montaser MA, Devlin H, Dickinson MR, Sloan P, Lloyd RE. Osseointegration of titanium metal implants in Erbium-YAG laser-prepared bone. Implant Dent. 1999;8(1):79-85.

126. Salina S, Maiorana C, Iezzi G, Colombo A, Fontana F, Piattelli A. Histological evaluation, in rabbit tibiae, of osseointegration of miniimplants in sites prepared with Er:YAG laser versus sites prepared with traditional burs. J Long Term Eff Med Implants. 2006; 16(2):145-156.

127. Schwarz F, Olivier W, Herten M, Sager M, Chaker A, Becker J. Influence of implant bed preparation using an Er:YAG laser on the osseointegration of titanium implants: a histomorphometrical study in dogs. J Oral Rehabil. 2007;34(4):273-281.

128. Kesler G, Romanos G, Koren R. Use of Er:YAG laser to improve osseointegration of titanium alloy implants - a comparison of bone healing. Int J Oral Maxillofac Implants. 2006;21(3):375-379.

129. Walsh LJ. The current status of laser applications in dentistry. Aust Dent J. 2003;48(3):146-155.

130. Convissar RA. The biologic rationale for the use of lasers in dentistry. Dent Clin North Am. 2004;48(4):771-794.

131. Lukac M, Hocevar F, Cencic S, et al. Effects of pulsed $\mathrm{CO}_{2}$ and Er:YAG lasers on enamel and dentin. Proc SPIE. 1993;1880:169-175.

132. Coluzzi DJ. An overview of laser wavelengths used in dentistry. Dent Clin North Am. 2000;44(4):753-765.

133. Maurer P, Kriwalsky MS, Block Veras R, Brandt J, Heiss C. Light microscopic examination of rabbit skulls following conventional and Piezosurgery osteotomy. Biomed Tech (Berl). 2007;52(5):351-355.

134. Frentzen M, Götz W, Ivanenko M, Afilal S, Werner M, Hering P. Osteotomy with 80-micros $\mathrm{CO}_{2}$ laser pulses - histological results. Lasers Med Sci. 2003;18(2):119-124.
135. Deppe H, Horch HH. Laser applications in oral surgery and implant dentistry. Lasers Med Sci. 2007;22(4):217-221.

136. Lee CY. A new method to harvest ramus bone using the erbium, chromium:yttrium-scandium-gallium-garnet laser. J Oral Maxillofac Surg. 2005;63(6):879-882.

137. Stübinger S, Kober C, Zeilhofer HF, Sader R. Er:YAG laser osteotomy based on refined computer-assisted presurgical planning: first clinical experience in oral surgery. Photomed Laser Surg. 2007;25(1):3-7.

138. Majaron B, Sustercic D, Lukac M, Skaleric U, Fundukc N. Heat diffusion and debris screening in Er:YAG laser ablation of hard biological tissues. Appl Phys B. 1998;66:1-9.

139. Abu-Serriah M, Critchlow H, Whitters CJ, Ayoub A. Removal of partially erupted third molars using an Erbium (Er):YAG laser: a randomised controlled clinical trial. Br J Oral Maxillofac Surg. 2004; 42(3):203-208.

140. Lee CY. Procurement of autogenous bone from ramus with simultaneous the mandibular third-molar removal for bone grafting using the Cr:YSGG laser: a preliminary report. J Oral Implantol. 2005; 31(1):32-38.

141. Stübinger S, Seitz O, Landes C, Bornand C, Robert S, Zeilhofer HF. Der Er:YAG Laser in der dentoalveolären Knochenchirurgie. Schweiz Monatsschr Zahnmed. 2007;117(11):1139-1143.

142. Leucht P, Lam K, Kim JB, et al. Accelerated bone repair after plasma laser corticotomies. Ann Surg. 2007;246(1):140-150.

143. Stübinger S, Jurgens P, Saldamli B, Sader R, Zeilhofer HF.Operative Entfernung verlagerter Weisheitszähne mittels Er: YAG Laserosteotomie. LaserZahnkeilkunde. 2006;3:19-25.

144. Stübinger S, Landes C, Seitz O, Sader R. Er:YAG laser osteotomy for intraoral bone grafting procedures: a case series with a fiber-optic delivery system. J Periodontol. 2007;78(12):2389-2394.

145. Stübinger S, von Rechenberg B, Zeilhofer HF, Sader R, Landes C. Er:YAG laser osteotomy for removal of impacted teeth: clinical comparison of two techniques. Lasers Surg Med. 2007;39(7):583-588.

146. Baraba A, Miletic I, Krmek SJ, Perhavec T, Bozic Z, Anic I. Ablative potential of the erbium-doped yttrium aluminium garnet laser and conventional handpieces: a comparative study. Photomed Laser Surg. 2009;27(6):921-927.

147. Lukac M, Marincek M, Grad L, Bozic Z. Dental laser drilling: state of art with the latest of the variable square pulse erbium dental laser systems. J Laser Health Acad. 2007;6:1-4.

148. Stübinger S, Ghanaati S, Saldamli B, Kirkpatrick CJ, Sader R. Er:YAG laser osteotomy: preliminary clinical and histological results of a new technique for contact-free bone surgery. Eur Surg Res. 2009;42(3): $150-156$

149. Stübinger S, Nuss K, Landes C, von Rechenberg B, Sader R. Harvesting of intraoral autogenous block grafts from the chin and ramus region: preliminary results with a variable square pulse Er:YAG laser. Lasers Surg Med. 2008;40(5):312-318.

150. Vescovi P, Manfredi M, Merigo E, et al. Surgical approach with Er:YAG laser on osteonecrosis of the jaws (ONJ) in patients under bisphosphonate therapy (BPT). Lasers Med Sci. 2010;25(1):101-113.

151. Angiero F, Sannino C, Borloni R, Crippa R, Benedicenti S, Romanos GE. Osteonecrosis of the jaws caused by bisphosphonates: evaluation of a new therapeutic approach using the Er:YAG laser. Lasers Med Sci. 2009;24(6):849-856.

152. Stübinger S, Dissmann JP, Pinho NC, Saldamli B, Seitz O, Sader R. A preliminary report about treatment of bisphosphonate related osteonecrosis of the jaw with Er:YAG laser ablation. Lasers Surg Med. 2009;41(1):26-30.

153. Coleton S. Lasers in surgical periodontics and oral medicine. Dent Clin North Am. 2004;48(4):937-962.

154. Parker S. Surgical laser use in implantology and endodontics. Br Dent J. 2007;202(7):377-386.

155. Romanos GE, Gutknecht N, Dieter S, Schwarz F, Crespi R, Sculean A. Laser wavelengths and oral implantology. Lasers Med Sci. 2009;24(6):961-970. 
156. Kuttenberger JJ, Stübinger S, Waibel A, et al. Computer-guided $\mathrm{CO}_{2}$-laser osteotomy of the sheep tibia: technical prerequisites and first results. Photomed Laser Surg. 2008;26(2):129-136.

157. Hohlweg-Majert B, Deppe H, Metzger MC, Stopp S, Wolff KD, Lueth TC. Bone treatment laser-navigated surgery. Lasers Med Sci. 2010; 25(1):67-71.

158. Stopp S, Svejdar D, Deppe H, Lueth TC. A new method for optimized laser treatment by laser focus navigation and distance visualization. Conf Proc IEEE Eng Med Biol Soc. 2007;2007:1738-1741.

159. Stopp S, Deppe H, Lueth T. A new concept for navigated laser surgery. Lasers Med Sci. 2008;23(3):261-266.

160. Stopp S, Svejdar D, von Kienlin E, Deppe H, Lueth TC. A new approach for creating defined geometries by navigated laser ablation based on volumetric 3-D data. IEEE Trans Biomed Eng. 2008;55(7): 1872-1880.

161. Rupprecht S, Tangermann-Gerk K, Wiltfang J, Neukam FW, Schlegel A. Sensor-based laser ablation for tissue specific cutting: an experimental study. Lasers Med Sci. 2004;19(2):81-88.
162. Rupprecht S, Tangermann-Gerk K, Schultze-Mosgau S, Neukam FW, Ellrich J. Neurophysiological monitoring of alveolar nerve function during sensor-controlled Er:YAG laser corticotomy in rabbits. Lasers Surg Med. 2005;36(3):186-192.

163. Rupprecht S, Tangermann K, Neukam FW, Wiltfang J. Er:YAG laser osteotomy directed by sensor controlled systems. J Craniomaxillofac Surg. 2003;31(6):337-342.

164. Beer F, Passow H. Construction of a standard test assembly for controlled laser studies in tissues: preliminary study on human bone material. Rev Sci Instrum. 2008;79(2 Pt 1):024301.

165. Steiner R. New laser technology and future applications. Medical Laser Appl. 2006;21:131-140.

166. Ivanenko MM, Hering P. Wet bone ablation with mechanically Q-switched high-repetition-rate $\mathrm{CO}_{2}$ laser. Appl Phys B. 1998;67: 395-397.

\section{Publish your work in this journal}

Clinical, Cosmetic and Investigational Dentistry is an international, peer-reviewed, open access, online journal focusing on the latest clinical and experimental research in dentistry with specific emphasis on cosmetic interventions. Innovative developments in dental materials, techniques and devices that improve outcomes and patient satisfac- tion and preference will be highlighted. The manuscript management system is completely online and includes a very quick and fair peerreview system, which is all easy to use. Visit http://www.dovepress. com/testimonials.php to read real quotes from published authors.

Submit your manuscript here: http://www.dovepress.com/clinical-cosmetic-and-investigational-dentistry-journal 